\title{
Microstructural Development of Fe-20mass\%Cr Alloys and Pure Copper Processed by Equal-Channel Angular Pressing
}

\author{
Muhammad Rifai ${ }^{1}$, Ryosuke Haga ${ }^{1}$, Hiroyuki Miyamoto ${ }^{2}$, Hiroshi Fujiwara ${ }^{2}$ \\ ${ }^{1}$ Graduate School of Science and Engineering, Doshisha University, Kyoto, Japan; ${ }^{2}$ Department of Mechanical Engineering, Dosh- \\ isha University, Kyoto, Japan. \\ Email: eum1504@mail4.doshisha.ac.jp
}

Received February $7^{\text {th }}, 2013$; revised March $4^{\text {th }}, 2013$; accepted April $8^{\text {th }}, 2013$

Copyright (C) 2013 Muhammad Rifai et al. This is an open access article distributed under the Creative Commons Attribution License, which permits unrestricted use, distribution, and reproduction in any medium, provided the original work is properly cited.

\begin{abstract}
Microstructural development of ultra low C, N, Fe-Cr alloy and pure copper processed by equal-channel angular pressing (ECAP) have been examined focusing on the initial stage of the formation of ultrafine grain structure. Fe-Cr alloys were pressed at $423 \mathrm{~K}$ while pure copper at room temperature for 1 to 3 passes via the route $\mathrm{Bc}$ to compare at the equivalent homologous temperature. Microstructural evolutions were characterized by electron backscatter diffraction (EBSD) image and transmission electron microscopy (TEM). It was found that deformation structures were mostly deformation-induced subboundaries in both the materials after one pass, but the fraction of high-angle grain boundary became higher in the Fe-Cr alloys than in pure copper in subsequent passes by increasing misorientation of the boundaries. The more enhanced formation of high angle boundaries in $\mathrm{Fe}-\mathrm{Cr}$ alloys was discussed in terms of the nature of crystal slip of FCC and BCC structures.
\end{abstract}

Keywords: EBSD; Copper; Ferritic Stainless Steel; Equal-Channel Angular Processing (ECAP); Grain Boundaries

\section{Introduction}

Application of SPD as a processing for fabricating ultrafine grained (UFG) material increased in popularity in the field of materials science and engineering. Equalchannel angular pressing (ECAP) is one of the SPD to produce UFG material and using a unique deformation processing by incremental shear restricted to the narrow zone parallel to the intersecting plane of the two channels $[1,2]$. The total amount of plastic strain is important as well as the amount of plastic strain imposed in one pass to produce ultrafine grained material [3]. Large shear deformation can be applied to material in every pressing without changing the billet shape.

UFG structures is generally considered to develop by grain subdivision mechanism, where grains are subdivided by deformation-induced subgrain boundaries or low-angle boundaries (LAB), followed by gradual increase of misorientation forming high-angle boundaries (HAB) [4]. The majority of papers on SPD materials have been devoted to the face-centered cubic (FCC) materials such as $\mathrm{Al}$ [5], $\mathrm{Cu}$ [6] and $\mathrm{Ni}$ [7]. For body-cen- tered cubic (BCC) metals, carbon steels have mostly been studied [8-16] from a practical view point.

Despite the recent studies on UFG low carbon steels [7-15], the underlying mechanism of deformation and UFG formation and their substantial difference from FCC metals in ECAP is not fully understood, largely due to complexities associated with chemical compositions, especially with solute carbon and cementite. As compared to FCC metals, BCC metals show predominant cross-slip by screw dislocation due to the high frictional stress associated with its non-planar core structure. Such difference in nature of crystal slip intrinsic to $\mathrm{BCC}$ and FCC may influence the development of UFG, in particular, the density of dislocation boundaries and their rate of transformation to $\mathrm{HAB}$ as a beginning stage of UFG formation. Dislocation glide and deformation microstructures of BCC metals are more sensitive to solute carbon or nitrogen than that of BCC metals. In this respect, pure BCC metals or interstitial-free (IF) metals should be used in order to clarify the microstructural development intrinsic to BCC structures. Although the literature on pure $\mathrm{BCC}$ or IF steels processed by ECAP has been reported 
[16-32], there are still very limited papers examining the microstructural evolution quantitatively in particular, the initial stage where dislocation substructure transforms into network of low/high angle grain boundaries.

There are several comparative studies of $\mathrm{BCC}$ and FCC metals, which report the differentiate of UFG formation and final grain size [22,33-38]. Comparative studies of UFG formation in BCC/FCC crystals were reported in accumulating roll bonding (ARB) $[14,33,34]$ and high pressure torsion (HPT) $[35,36]$. ARB processed material shows higher fraction of high angle grain boundary in IF-Steel, than in OFHC-Cu [33]. The large amount of LAB fraction in OFHC-Cu was attributed to recovery and recrystallization during the ARB process [33]. However, in ARB, pure iron or steels as BCC material were mostly rolled at $773 \mathrm{~K}$ to obtain good bonding while aluminum as FCC material was rolled at room temperature or $473 \mathrm{~K}$. Namely, the formation of UFG is compared at different homologous temperature [33]. Therefore, the influence of thermal activation is different in both the materials on the formation of UFG. In this context, we carried out experiments at the same homologous temperature, focusing on the difference in microstructural evolution of FCC and BCC at the equivalent thermal activation during ECAP. Dislocation structures, and microscopic parameter such as the fraction and spacing of $\mathrm{HAB}$, distribution of misorientation and dislocation density of pure copper and $\mathrm{Fe}-\mathrm{Cr}$ with extremely low $\mathrm{C}, \mathrm{N}$ were carefully examined and compared focusing on the initial stage of UFG formation during ECAP.

\section{Experimental}

The chemical composition of pure copper was $99.99 \%$ purity and $\mathrm{Fe}-\mathrm{Cr}$ alloys were $\mathrm{Cr} 20.03$; C 0.0004 ; N 0.0013 and $\mathrm{Fe}$ balance (in mass percent). Pure copper was machined with dimensions $20 \mathrm{~mm}$ in diameter and $100 \mathrm{~mm}$ in length, and $\mathrm{Fe}-\mathrm{Cr}$ alloys dimensions $3.95 \mathrm{~mm}$ $\times 3.95 \mathrm{~mm} \times 40 \mathrm{~mm}$ for ECAP pressing. The ECAP procedures were carried out using a split die with two channels intersecting at inner angle of $90^{\circ}$ and outer angle of $0^{\circ}$, as is seen in Figure 1(a). ECAP of Fe-Cr alloys were carried out at $423 \mathrm{~K}$ while pure copper at room temperature in order to examine at the equal temperature ratio to melting temperature for each material. The samples lubricated with $\mathrm{MoS}_{2}$ were pressed from one to three passes through the so-called Route $\mathrm{Bc}$ as is seen in Figure 1(b). The original microstructure of as-received sample was observed using an optical microscope (OM), as is seen in Figure 2, original grain size of $\mathrm{Fe}-\mathrm{Cr}$ alloy is much larger than that of pure copper. Microstructure quantification using orientation map observation and mechanical properties can be analyzed during grain refinement process using SPD. A scanning electron micro-

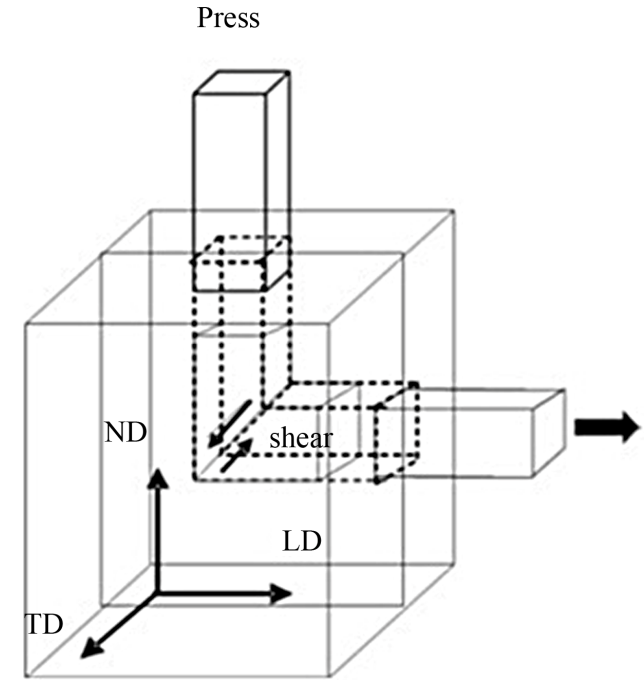

(a)
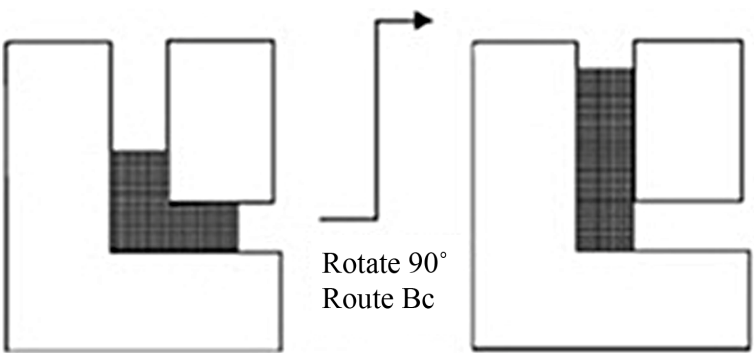

(b)

Figure 1. (a) Schema of ECAP; (b) Route Bc of ECAP.
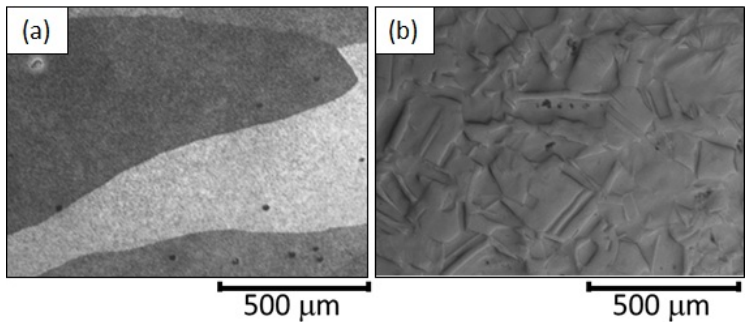

Figure 2. Microstructure using OM for (a) Fe-Cr alloys; (b) Pure copper.

scope of field-emission type (FE-SEM, JSM 7001F), equipped with electron back-scattered diffraction (EBSD, Oxford Instrument Co.) image, and a transmission electron microscope (TEM) were used to examine the microstructures. EBSD orientation maps were processed using $\mathrm{INCA}^{\mathrm{TM}}$ software. Thin foils for TEM were polished using abrasive papers to about $100 \mu \mathrm{m}$ thick and then thinned by a twin-jet polishing facility using a solution of nitric acid 33\% and 67\% methanol for pure copper and acetic acid $40 \%$, phosphoric acid $30 \%$, nitric acid $20 \%$ and distilled water $10 \%$ for $\mathrm{Fe}-\mathrm{Cr}$ alloys. Hardness experiments were performed on a Vickers hardness testing machine at room temperature. 


\section{Results}

Three-dimensional orientation image maps (OIM) were obtained by EBSD after ECAP are shown in Figure 3. It is apparent that grains are more finely subdivided in $\mathrm{Fe}-\mathrm{Cr}$ alloys than pure copper after the first pressing in spite that the former material has larger grain size before ECAP. Furthermore, arrays of planar and extended grain boundaries are developed parallel to the macroscopic shear plane of ECAP in $\mathrm{Fe}-\mathrm{Cr}$ alloys whereas grain boundaries are rather curved in copper. After three passes, both materials were finely fragmented, but boundary spacing was still smaller in $\mathrm{Fe}-\mathrm{Cr}$ alloys.

Misorientation maps showing low-angle boundaries (LAB) $\left(2^{\circ} \leq \theta<15^{\circ}\right)$ and high-angle boundaries (HAB) $\left(\theta \geq 15^{\circ}\right)$ with green and red lines, respectively, are shown in Figure 4. Because of low orientation resolution, boundaries with misorientation smaller than $2^{\circ}$ were omited. As was mentioned in Figure 3, planar array of grain boundaries was noticeable in $\mathrm{Fe}-\mathrm{Cr}$ alloys after one or two passes. In $\mathrm{Fe}-\mathrm{Cr}$ alloy, higher density of LABs with spacing smaller than $1 \mu \mathrm{m}$ were formed after one pressing, and then the HAB fraction becomes higher by increasing misorientation angle with increasing strain. On the other hand, density of LAB increased after two and

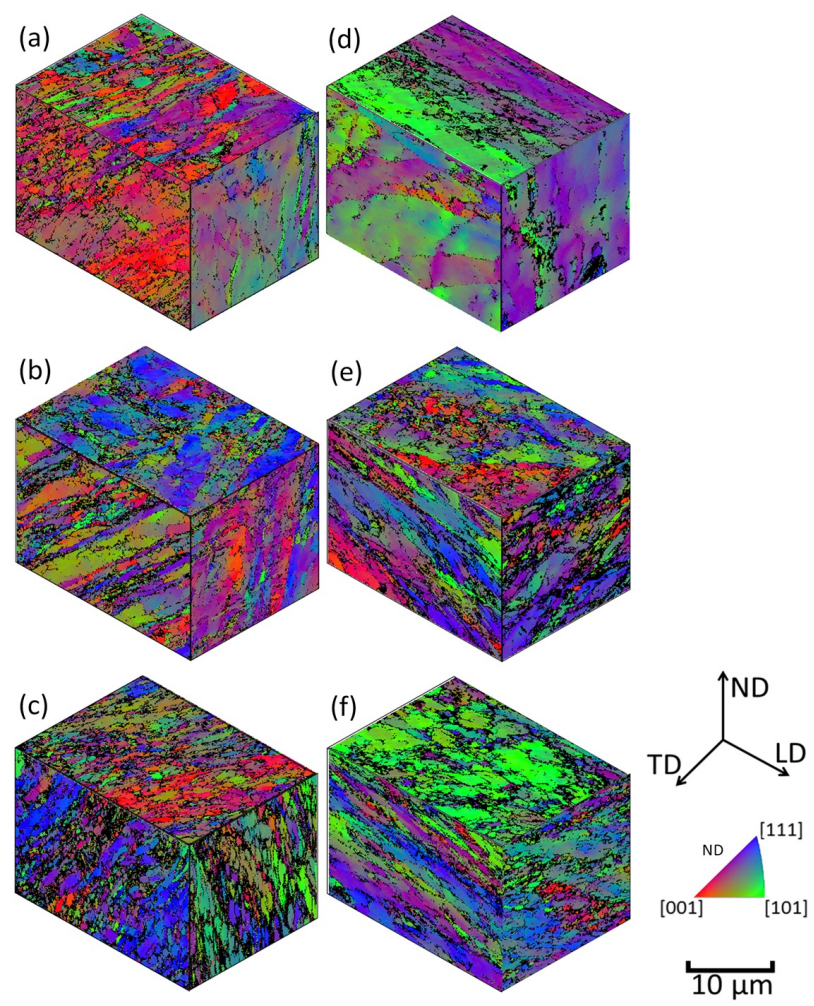

Figure 3. 3D representation EBSD orientation color map of Fe-Cr alloys after ECAP (a) One pass; (b) Two passes; (c) Three passes, and pure copper after ECAP (d) One pass; (e) Two passes; and (f) Three passes.
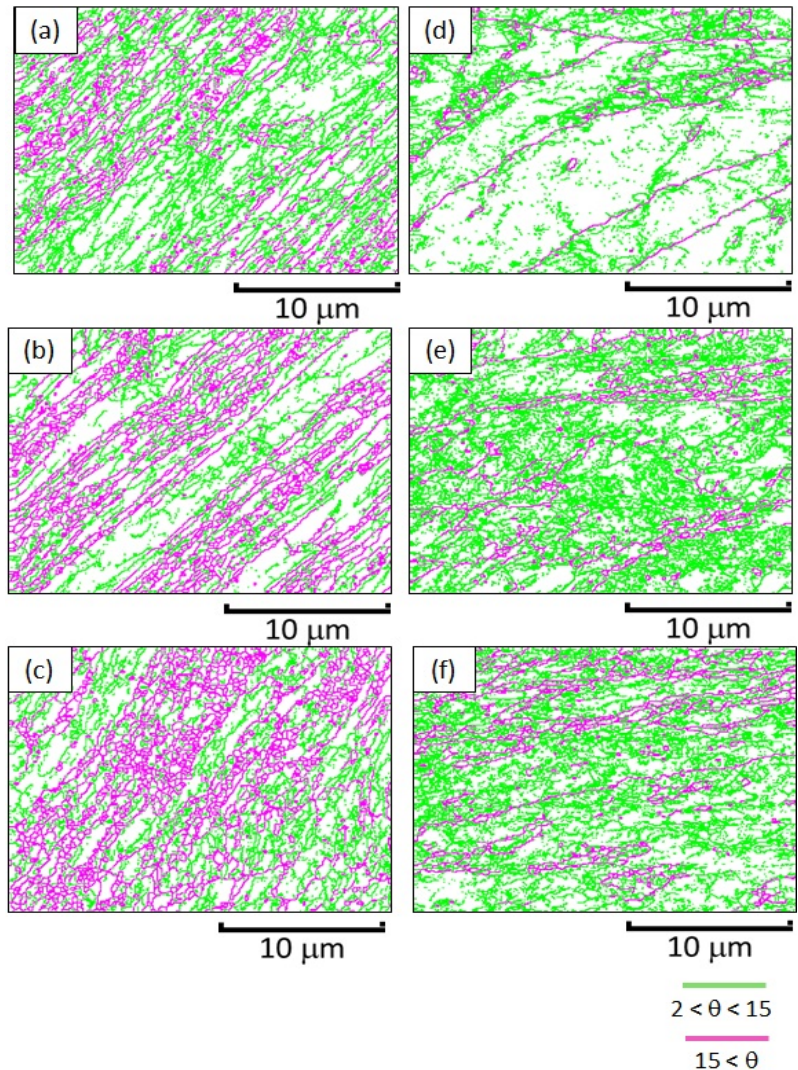

Figure 4. Misorientation map of Fe-Cr alloys after ECAP (a) One pass; (b) Two passes; (c) Three passes, and pure copper after ECAP (d) One pass; (e) Two passes; and (f) Three passes.

three passes while HAB were very scarce in pure copper, and they are still scarcer after three passes. It seems that lines defined as LABs in the misorientation map are diffuse, and mostly still dislocation cell boundaries in pure copper.

Distribution of misorientation angle was obtained from EBSD observation after one to three passes of ECAP as shown in Figure 5. Result of single pass for both the materials shows boundary misorientation with a peak in the range of $2^{\circ}-4^{\circ}$ with low HAB misorientation distribution. After two and three passes, the difference became noticeable between both the materials. Misorientation distribution of $\mathrm{Fe}-\mathrm{Cr}$ alloys shows two small peaks at low and high angle misorientation with relatively flat distribution while pure copper shows peaks only at misorientation smaller than 5 degrees, and it shows average apparently increased with the number of ECAP passes in Figure 5. Quantitative analysis of microstructures by EBSD is shown in Figure 6. As shown in Figures 6(a) and (b), fraction of HAB and average misorientation is higher in $\mathrm{Fe}-\mathrm{Cr}$ alloys and increased until three passes with considers to equivalent strain. The equivalent strain imposed on a sample as it passes through an ECAP die 


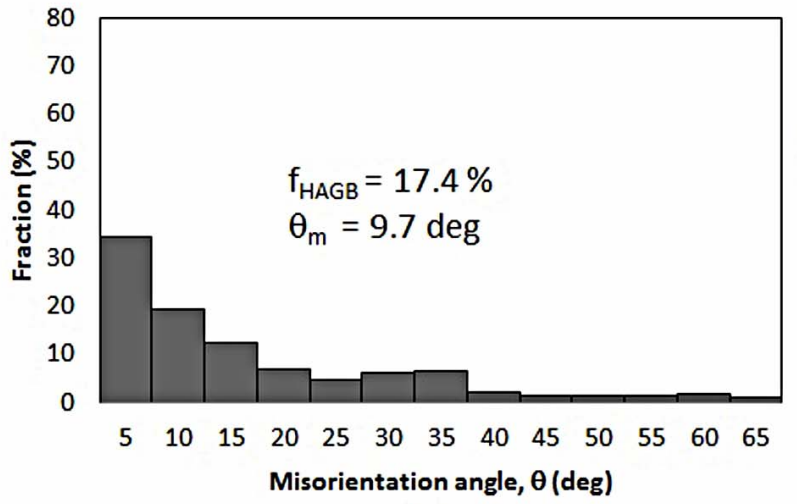

(a)

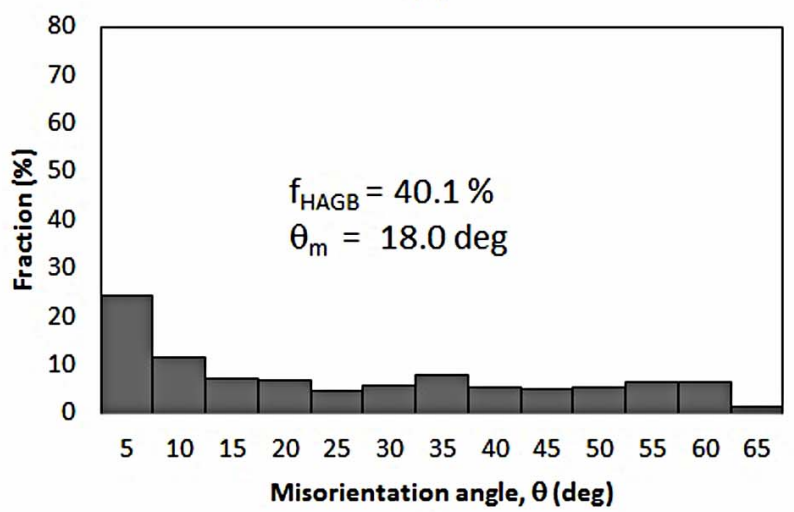

(b)

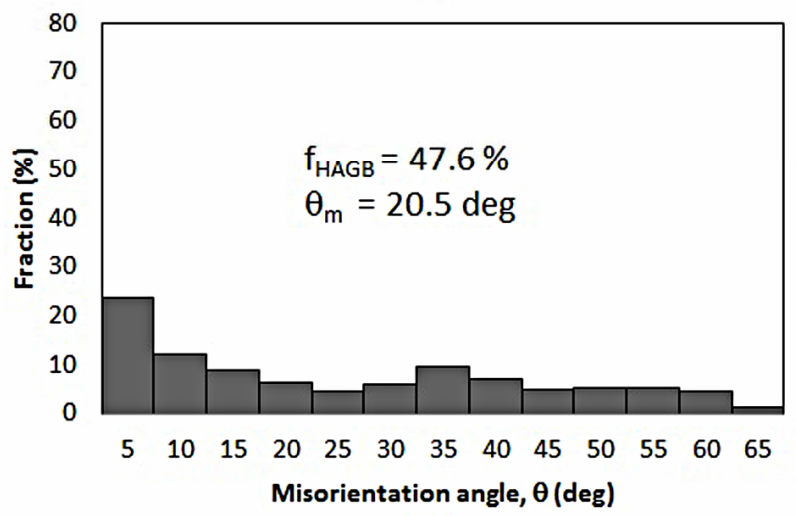

(c)

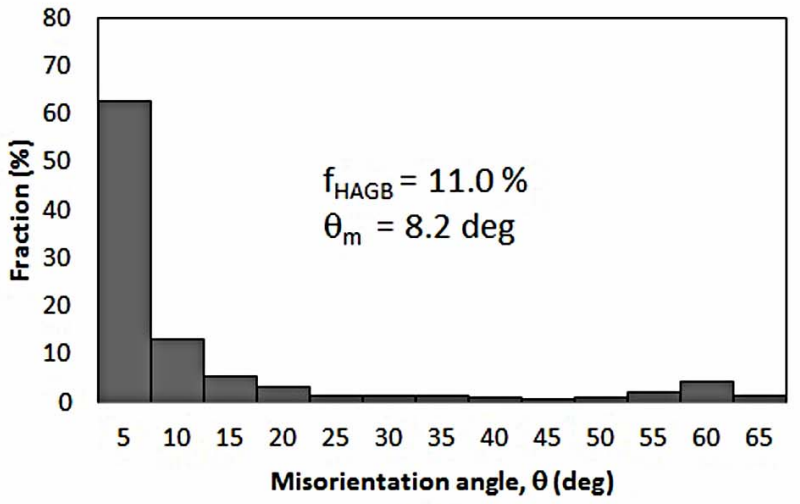

(d)

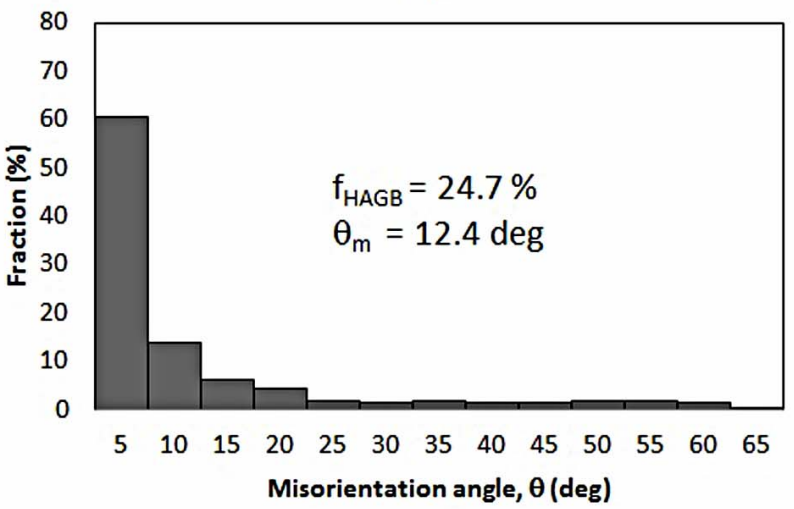

(e)

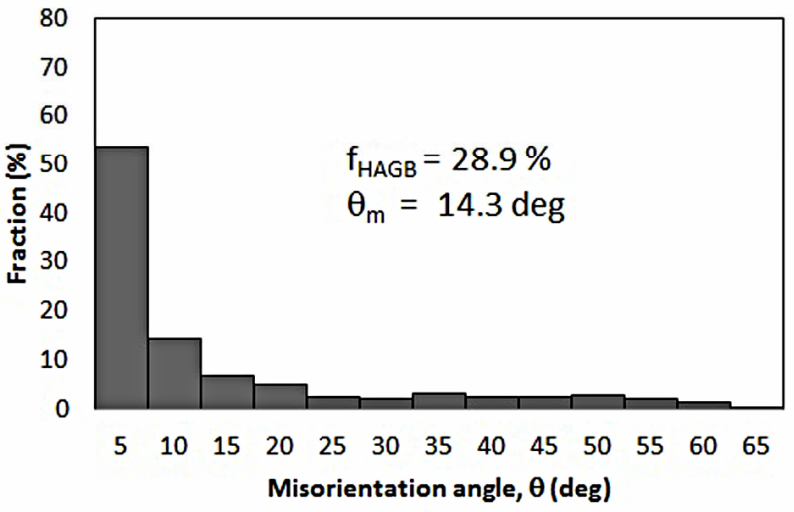

(f)

Figure 5. Distribution of misorientation of Fe-Cr alloys after ECAP (a) One pass; (b) Two passes; (c) Three passes, and pure copper after ECAP (d) One pass; (e) Two passes; and (f) Three passes.

was given in the reference [39]. However, while, boundary spacing decreased considerably after two passes in both the materials, there were smaller changes after three passes, as seen in Figure 6(c).

Microstructure was observed using TEM (Figure 7). Dislocation cells structures were predominant after one pass in both the materials. However, elongated sub grains can be found out at $\mathrm{Fe}-\mathrm{Cr}$ alloys and they became finely divided by sharper boundaries after three passes. On the other hand, subboundaries in pure copper after three passes are still diffused, and seem to be still mainly dislocation cell structures. Dislocation density inside grains was estimated from TEM images by Ham's interception method [40]. The thickness of specimen was estimated $245 \mathrm{~nm}$ for calculating dislocation density with Ham's interception method. $\mathrm{Fe}-\mathrm{Cr}$ alloys and pure copper show that similar trend of dislocation density as shown in Figure 8 with increasing number of passes. 


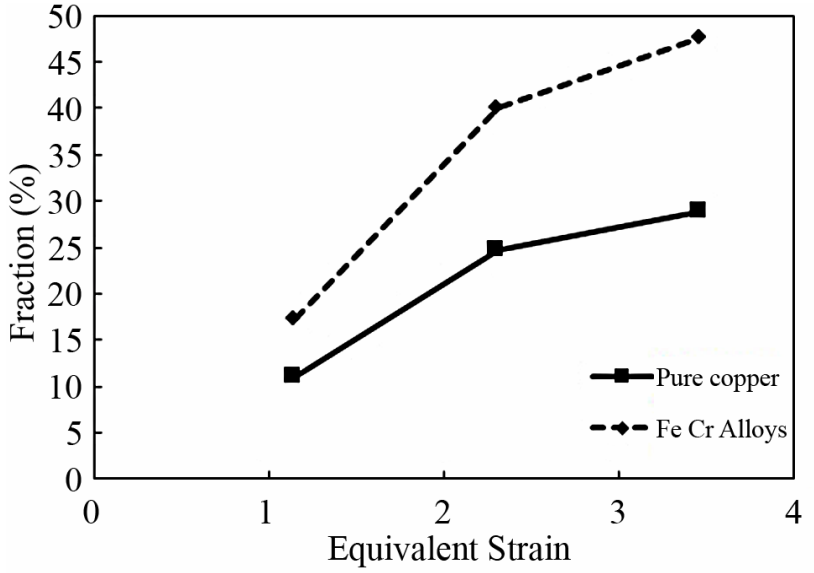

(a)

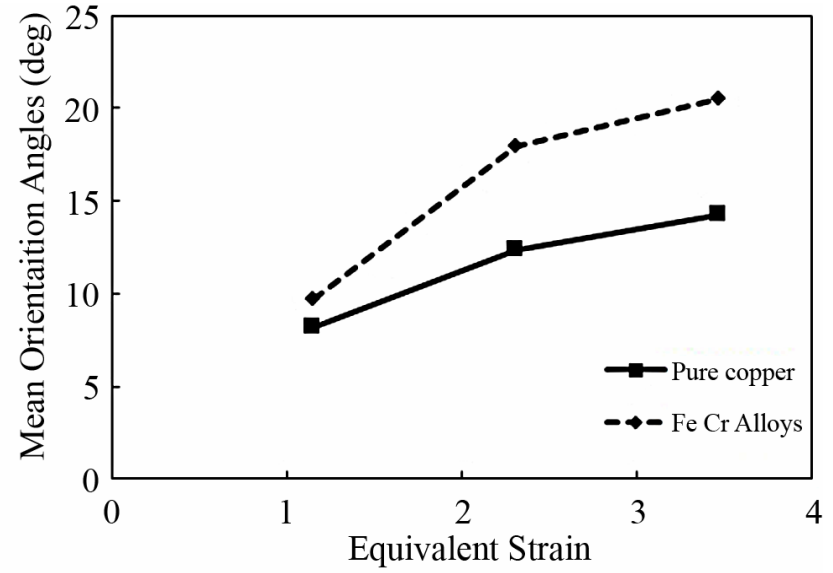

(b)

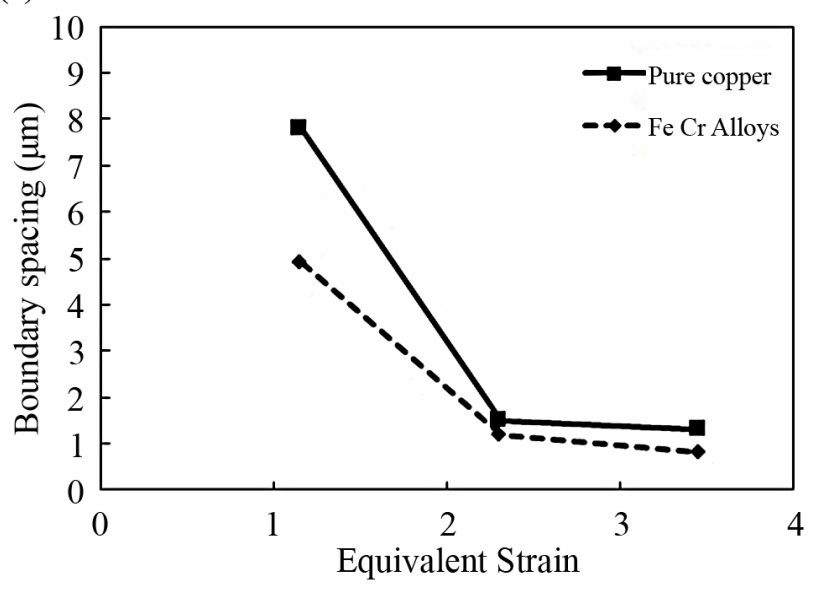

(c)

Figure 6. Microstructural parameters as a function of equivalent strain, (a) Fraction of HAB; (b) Average misorientation angle; and (c) Average boundary spacing.
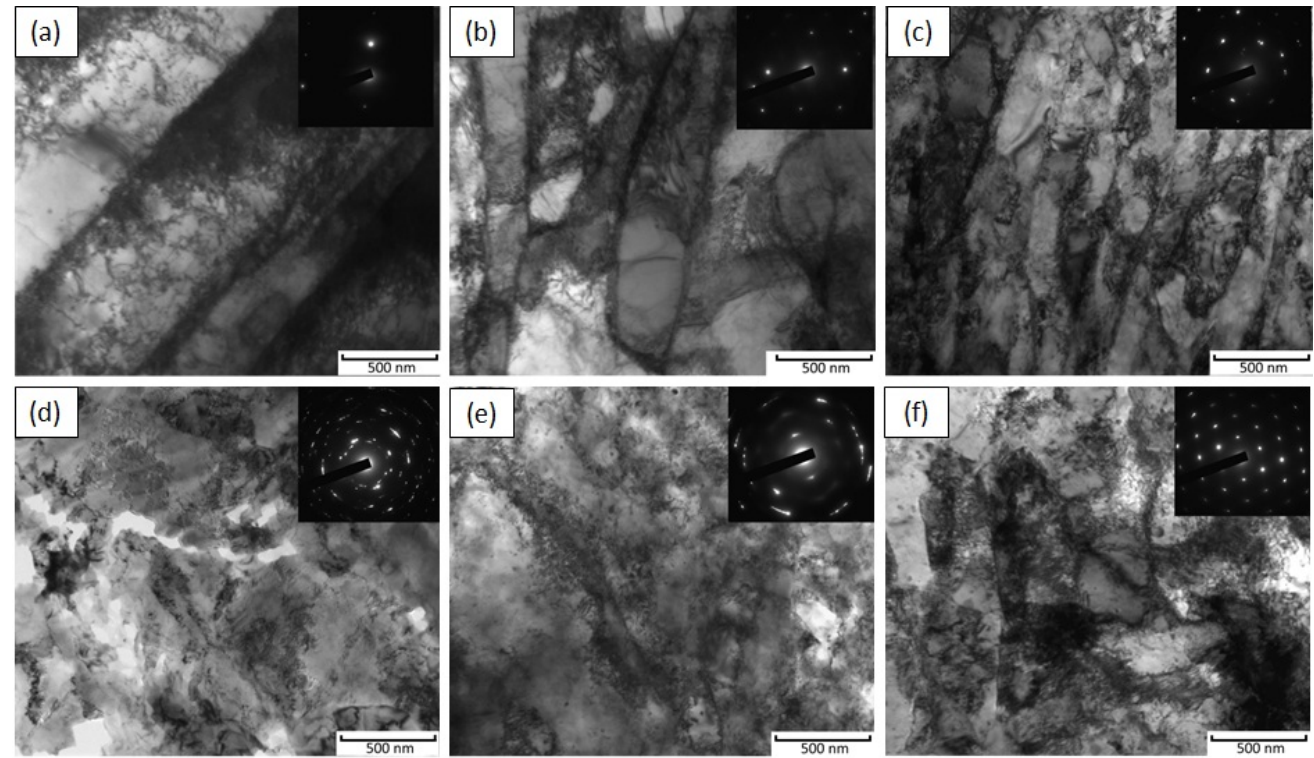

Figure 7. Microstructure using TEM of pure copper after ECAP (a) One pass; (b) Two passes; (c) Three passes, and Fe-Cr alloys after ECAP (d) One pass; (e) Two passes; and (f) Three passes. 


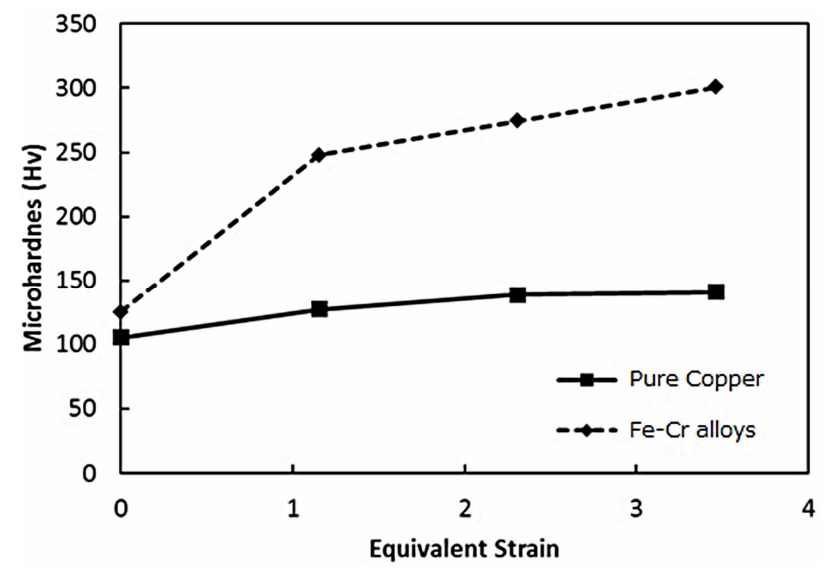

Figure 8. Dislocation density after ECAP for Fe-Cr alloys and pure copper.

Hardness change after ECAP is shown in Figure 9. Hardness after a single pass increase significantly in both the materials, but the rate of becoming harder is higher in Fe-Cr alloys. It is probably because of higher HAB density with comparable dislocation density.

\section{Discussion}

Finer grain subdivision with higher fraction of HAB in Fe-Cr alloys in the initial stage during one to three passes ECAP of the formation of UFG structures is now apparent as compared with pure copper. Since both materials have high purity, especially $\mathrm{Fe}-\mathrm{Cr}$ alloy is interstitial-free, we can discuss the microstructural difference in terms of nature of crystal slip intrinsic to $\mathrm{FCC} / \mathrm{BCC}$ structures. Since Peierls potential of screw dislocations is higher than that of edge dislocation in BCC crystals, the plastic deformation is rate-controlled by screw dislocations [41], and glided area swept by screw dislocation is higher than that by edge dislocation [42]. Thus, the nature of slip intrinsic to screw dislocation such as cross slip, or pensile glide become pronounced and influential on the macroscopic behavior of plastic deformation. According to the grain subdivision mechanism [4], grains are subdivided by deformation-induced subboundaries in the initial state. These subboundaries are generally planar and extended, which is typical features of geometrically necessary boundaries (GNBs) [4]. In general, these boundaries are parallel to the trace of active slip planes, and are parallel to $\{110\}$ trace in the present study [43]. The dislocations on various $\{110\}$, and possibly $\{211\}$, with the common slip direction form the dislocation boundaries. With increasing plastic strain, subboundaries increase their misorientation by absorbing lattice dislocations from the adjoining grains $[4,42]$. In $\mathrm{BCC}$, high frictional stress of screw dislocations and resultant frequent cross slip promote dislocation multiplications and the formation of

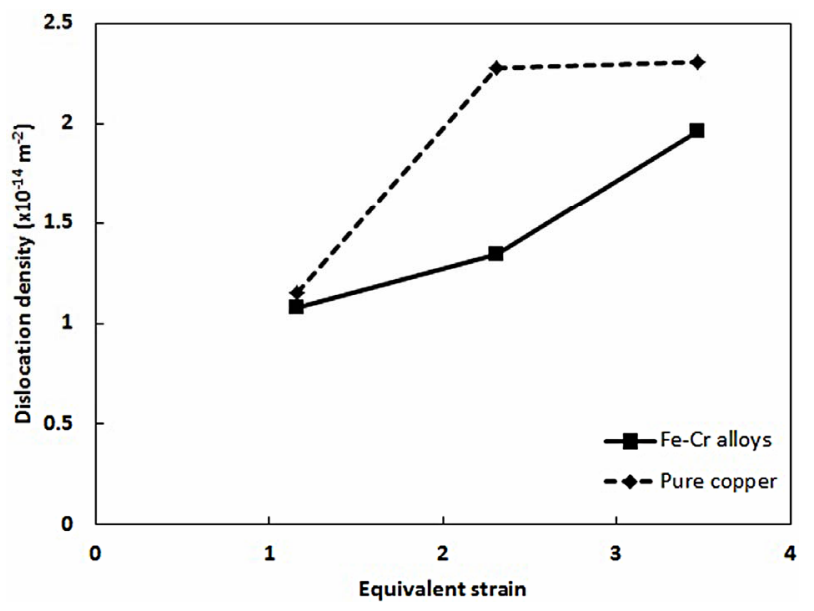

Figure 9. Microhardness after ECAP for Fe-Cr alloys and pure copper.

subgrain boundaries [41]. This is the reason why the finer subgrains were formed in earlier stage after one pressing.

In FCC, the dislocations tend to form pile-up rather than cross slip, then they are accumulated as plastic strain rather than absorbed in the grain boundaries and they are hard to be restructured as grain boundary dislocation. This may explain the reason why the fraction $\mathrm{HAB}$ is lower after three passes in pure copper in spite of comparable low-angle sub grain/cell size with $\mathrm{Fe}-\mathrm{Cr}$ alloy. In this case, dislocation density should be higher in pure copper than $\mathrm{Fe}-\mathrm{Cr}$ alloy at the same strain level. Dislocation density of $\mathrm{Cu}$ shows lower than $\mathrm{Fe}-\mathrm{Cr}$ alloys as shown in the Figure 8, and it seems inconsistent with the explanation mentioned above. Possible explanation of lower dislocation of pure copper is dynamic recrystallization, which may occur during ECAP. Inhomogeneous microstructures observed in Figure 3 with large and small grains may be originated from the dynamic recrystallization. ARB $\mathrm{Cu}$ was carried out at ambient temperature with six cycles $(\varepsilon=4.8)$. The large fraction of low angle boundaries in copper was attributed to partial recrystallization during the ARB process due to high purity of the material and adiabatic heating. The possibility of dynamic recrystallization in copper during SPD is also reported in Accumulative Roll Bonding (ARB) [33].

\section{Conclusions}

The microstructural evolution of $\mathrm{Fe}-\mathrm{Cr}$ alloys and pure copper processed by ECAP for up to three passes was quantitatively analyzed by EBSD focusing on the initial stage of UFG formation. The deformation microstructure after one pass consist of deformation-induced extended subrain boundaries typical to the geometrically necessary boundaries. The density of the boundaries is higher in 
$\mathrm{Fe}-\mathrm{Cr}$ alloys than pure copper.

With increasing ECAP passes, the fraction of HAB and mean misorientation angle increase, and HAB spacing decreases. This phenomenon is noticeable in $\mathrm{Fe}-\mathrm{Cr}$ steels, and can be explained in terms of slip behavior intrinsic to $\mathrm{BCC}$ structure.

\section{REFERENCES}

[1] R. Z. Valiev, R. K. Islamgaliev and I. V. Alexandrov, "Bulk Nanostructured Materials from Severe Plastic Deformation," Progress in Materials Science, Vol. 45, No. 2, 2000, pp. 103-189. doi:10.1016/S0079-6425(99)00007-9

[2] R. Z. Valiev and T. G. Langdon, "Principles of EqualChannel Angular Pressing as a Processing Tool for Grain Refinement," Progress in Materials Science, Vol. 51, No. 7, 2006, pp. 881-981. doi:10.1016/j.pmatsci.2006.02.003

[3] K. Nakashima, Z. Horita, M. Nemoto and T. G. Langdon, "Influence of Channel Angle on the Development of Ultrafine Grains in Equal-Channel Angular Pressing," Acta materialia, Vol. 46, No. 5, 1998, pp. 1589-1599. doi:10.1016/S1359-6454(97)00355-8

[4] N. Hansen and D. J. Jensen, "Development of Microstructure in FCC Metals during Cold Work," Philosophical Transactions of the Royal Society of London Series A, Vol. 357, No. 1756, 1999, pp. 1447-1469.

[5] Y. Fukuda, K. Oh-ishi, Z. Horita and T. G. Langdon, "Processing of a Low-Carbon Steel by Equal-Channel Angular Pressing," Acta Materialia, Vol. 50, No. 6, 2002, pp. 1359-1368. doi:10.1016/S1359-6454(01)00441-4

[6] C. X. Huang, H. J. Yang, S. D Wu and Z. F. Zhang, "Microstructural Characterizations of $\mathrm{Cu}$ Processed by ECAP from 4 to 24 Passes," Material Science Forum, Vol. 584586, 2008, pp. 333-337.

doi:10.4028/www.scientific.net/MSF.584-586.333

[7] D. H. Shin and K.-T. Park, "Ultrafine Grained Steels Processed by Equal Channel Angular Pressing," Materials Science and Engineering: A, Vol. 410-411, 2005, pp. 299-302. doi:10.1016/j.msea.2005.08.025

[8] D. H. Shin, I. Kim, J. Kim and K. T. Park, "Grain Refinement Mechanism during Equal-Channel Angular Pressing of a Low-Carbon Steel," Acta Materialia, Vol. 49, No. 13, 2001, pp. 1285-1292.

doi:10.1016/S1359-6454(01)00165-3

[9] D. H. Shin, B. C. Kim, W. Y. Choo and K.-T. Park, "Microstructural changes in Equal Channel Angular Pressed Low Carbon Steel by Static Annealing," Acta Materialia, Vol. 48, No. 12, 2000, pp. 3245-3252. doi:10.1016/S1359-6454(00)00090-2

[10] C. X. Huang, Y. L. Gao, G. Yang, S. D. Wu, G. Y. Li and S. X. Li, "Bulk Nanocrystalline Stainless Steel Fabircated by Equal Channel Angular Pressing," Journal of Materials Research, Vol. 21, No. 7, 2006, pp. 1687-1692. doi:10.1557/jmr.2006.0214

[11] J. Kim, I. Kim and D. H. Shin, "Development of Deformation Structures in Low Carbon Steel by Equal Channel Angular Pressing," Scripta Materialia, Vol. 45, No. 4,
2001, pp. 421-426. doi:10.1016/S1359-6462(01)01029-6

[12] J. C. Pang, M. X. Yang, G. Yang, S. D. Wu, S. X. Li and Z. F. Zhang, "Tensile and Fatigue Properties of Ultrafine-Grained Low-Carbon Steel Processed by Equal Channel Angular Pressing," Materials Science and Engineering: $A$, Vol. 553, 2012, pp. 157-163. doi:10.1016/j.msea.2012.06.005

[13] D. H. Shin, W.-J. Kim and W. Y. Choo, "Grain Refinement of a Commercial $0.15 \%$ C Steel by Equal-Channel Angular Pressing," Scripta Materialia, Vol. 41, No. 3, 1999, pp. 259-262. doi:10.1016/S1359-6462(99)00156-6

[14] D. H. Shin, C. W. Seo, J. Kim, K. T. Park and W. Y. Choo, "Microstructures and Mechanical Properties of Equal-Channel Angular Pressed Low Carbon Steel," Scripta Materialia, Vol. 42, No. 7, 2000, pp. 695-699. doi:10.1016/S1359-6462(99)00422-4

[15] Y. I. Son, Y. K. Lee, K.-T. Park, C. S. Lee and D. H. Shin, "Ultrafine Grained Ferrite-Martensite Dual Phase Steels Fabricated via Equal Channel Angular Pressing: Microstructure and Tensile Properties," Acta Materialia, Vol. 53, No. 11, 2005, pp. 3125-3134. doi:10.1016/j.actamat.2005.02.015

[16] G. Yang, C. X. Huang, C. Wang, L. Y. Zhang, C. Hu, Z. F. Zhang and S. D. Wu, "Enhancement of Mechanical Properties of Heat-Resistant Martensitic Steel Processed by Equal Channel Angular Pressing," Materials Science and Engineering: A, Vol. 515, No. 1-2, 2009, pp. 199206. doi:10.1016/i.msea.2009.03.031

[17] M. A. Gibbs, K. T. Hartwig, L. R. Cornwell, R. E. Goforth and E. A. Payzant, "Texture Formation in Bulk Iron Processed by Simple Shear," Scripta Materialia, Vol. 39, No. 12, 1998, pp. 1699-1704. doi:10.1016/S1359-6462(98)00384-4

[18] M. Suś-Ryszkowska, T. Wejrzanowski, Z. Pakieła and K. J. Kurzydłowski, "Microstructure of ECAP Severely Deformed Iron and Its Mechanical Properties," Materials Science and Engineering: A, Vol. 369, No. 1-2, 2004, pp. 151-156. doi:10.1016/j.msea.2003.10.318

[19] B. Han, F. Mohamed and E. Lavernia, "Mechanical properties of iron processed by severe plastic deformation", Metallurgical and Materials Transactions A, Vol. 34, No. 1, 2003, pp. 71-83.

[20] B. Q. Han, E. Lavernia and F. A. Mahamed, "Dislocation Structure and Deformation in Iron Processed by EqualChannel-Angular Pressing," Metallurgical and Materials Transactions A, Vol. 35, No. 4, 2004, pp. 1343-1350.

[21] A. A. Gazder, W. Cao, C. H. J. Davies and E. V. Pereloma, "An EBSD Investigation of Interstitial-Free Steel Subjected to Equal Channel Angular Extrusion," Materials Science and Engineering: A, Vol. 497, No. 1-2, 2008, pp. 341-352. doi:10.1016/j.msea.2008.07.030

[22] A. A. Gazder, F. D. Torre, C. F. Gu, C. H. J. Davies and E. V. Pereloma, "Microstructure and Texture Evolution of BCC and FCC Metals Subjected to Equal Channel Angular Extrusion," Materials Science and Engineering: A, Vol. 415, No. 1-2, 2006, pp. 126-139. doi:10.1016/j.msea.2005.09.065

[23] S. S. Hazra, E. V. Pereloma and A. A. Gazder, "Micro- 
structure and Mechanical Properties after Annealing of Equal-Channel Angular Pressed Interstitial-Free Steel," Acta Materialia, Vol. 59, No. 10, 2011, pp. 4015-4029. doi:10.1016/j.actamat.2011.03.026

[24] S. Li, A. A. Gazder, I. J. Beyerlein, C. H. J. Davies and E. V. Pereloma, "Microstructure and Texture Evolution during Equal Channel Angular Extrusion of Interstitial-Free Steel: Effects of Die Angle and Processing Route," Acta Materialia, Vol. 55, No. 3, 2007, pp. 1017-1032. doi:10.1016/j.actamat.2006.09.022

[25] S. N. Mathaudhu and K. Ted Hartwig, "Grain Refinement and Recrystallization of Heavily Worked Tantalum," Materials Science and Engineering: A, Vol. 426, No. 1-2, 2006, pp. 128-142. doi:10.1016/j.msea.2006.03.089

[26] K. Máthis, T. Krajňák, R. Kužel and J. Gubicza, "Structure and Mechanical Behaviour of Interstitial-Free Steel Processed by Equal-Channel Angular Pressing," Journal of Alloys and Compounds, Vol. 509, No. 8, 2011, pp. 3522-3525. doi:10.1016/j.jallcom.2010.12.142

[27] O. Saray, G. Purcek and I. Karaman, "Principles of Equal-Channel Angular Sheet Extrusion (ECASE): Application to IF-Steel Sheets," Review on Advanced Materials Science, Vol. 25, 2010, pp. 42-51.

[28] O. Saray, G. Purcek, I. Karaman, T. Neindorf and H. J. Maier, "Equal-Channel Angular Sheet Extrusion of Interstitial-Free (IF) Steel: Microstructural Evolution and Mechanical Properties," Materials Science and Engineering: A, Vol. 528, No. 21, 2011, pp. 6573-6583. doi:10.1016/j.msea.2011.05.014

[29] Q. Wei, T. Jiao, S. N. Mathaudhu, E. Ma, K. T. Hartwig and K. T. Ramesh, "Microstructure and Mechanical Properties of Tantalum after Equal Channel Angular Extrusion (ECAE)," Materials Science and Engineering: A, Vol. 358, No. 1-2, 2003, pp. 266-272. doi:10.1016/S0921-5093(03)00305-8

[30] Q. Wei, L. Kecskes, T. Jiao, K. T. Hartwig, K. T. Ramesh and E. Ma, "Adiabatic Shear Banding in Ultrafine-Grained Fe Processed by Severe Plastic Deformation," Acta Materialia, Vol. 52, No. 7, 2004, pp. 1859-1869. doi:10.1016/i.actamat.2003.12.025

[31] G. Yang, M.-X. Yang, Z.-D. Liu and C. Wang, "ThreeDimensional Microstructures and Tensile Properties of Pure Iron during Equal Channel Angular Pressing," Journal of Iron and Steel Research, International, Vol. 18, No. 12, 2011, pp. 40-44. doi:10.1016/S1006-706X(12)60007-7

[32] H. R. Z. Sandim, H. H. Bernardi, B. Verlinden and D. Raabe, "Equal Channel Angular Extrusion of Niobium Single Crystals," Materials Science and Engineering: A, Vol. 467, No. 1-2, 2007, pp. 44-52.

\section{doi:10.1016/j.msea.2007.02.086}

[33] B. L. Li, N. Tsuji and N. Kamikawa, "Microstructure Homogeneity in Various Metallic Materials Heavily Deformed by Accumulative Roll-Bonding," Materials Science and Engineering: A, Vol. 423, No. 1-2, 2006, pp. 331-342. doi:10.1016/j.msea.2006.02.028

[34] N. Tsuji, Y. Ito, Y. Saito and Y. Minamino, "Strength and Ductility of Ultrafine Grained Aluminum and Iron Produced by ARB and Annealing," Scripta Materialia, Vol. 47, No. 12, 2002, pp. 893-899. doi:10.1016/S1359-6462(02)00282-8

[35] F. Wetscher and R. Pippan, "Cyclic High-Pressure Torsion of Nickel and Armco Iron," Philosophical Magazine, Vol. 86, No. 36, 2006, pp. 5867-5883. doi: $10.1080 / 14786430600838288$

[36] F. Wetscher, A. Vorhauer and R. Pippan, "Strain Hardening during High Pressure Torsion Deformation," Materials Science and Engineering: A, Vol. 410-411, 2005, pp. 213-216. doi:10.1016/j.msea.2005.08.027

[37] X. Huang, N. Kamikawa and N. Hansen, "Increasing the Ductility of Nanostructured Al and Fe by Deformation," Materials Science and Engineering: A, Vol. 493, No. 1-2, 2008, pp. 184-189. doi:10.1016/j.msea.2007.04.131

[38] X. Huang, N. Kamikawa, N. Tsuji and N. Hansen, "Nanostructured Aluminum and IF Steel Produced by rolling-A Comparative Study," ISIJ International, Vol. 48, No. 8, 2008, pp. 1080-1087. doi:10.2355/isijinternational.48.1080

[39] Y. Iwahashi, J. Wang, Z. Horita, M. Nemoto and T. G. Langdon, "Principle of Equal-Channel Angular Pressing for the Processing of Ultra-Fine Grained Materials," Scripta Materialia, Vol. 35, No. 2, 1996, pp. 143-146. doi:10.1016/1359-6462(96)00107-8

[40] R. K. Ham, "The Determination of Dislocation Densities in Thin Films," Philosophical Magazine, Vol. 6, No. 69, 1961, pp. 1183-1184. doi:10.1080/14786436108239679

[41] A. S. Argon and S. R. Maloof, "Plastic Deformation of Tungsten Single Crystals at Low Temperatures," Acta Metallurgica, Vol. 14, No. 11, 1966, pp. 1449-1461. doi:10.1016/0001-6160(66)90165-9

[42] H. Mughrabi, K. Herz and X. Stark, "The Effect of Strain-Rate on the Cyclic Deformation Properties of $\alpha$ Iron Single Crystal," Acta Metallurgica, Vol. 24, No. 7, 1976, pp. 659-668. doi:10.1016/0001-6160(76)90086-9

[43] J. A. Wert, X. Huang, C. Winther, W. Pantleon and H. F. Poulsen, "Revealing Deformation Microstructures," $\mathrm{Ma}$ terials Today, Vol. 10, No. 9, 2007, pp. 24-32. doi:10.1016/S1369-7021(07)70206-7 